\title{
Appeal against THE DECISION OF THE HUNTING ASSOCIATION REGARDING THE EXCLUSION FROM AMONG ITS MEMBERS. SELECTED PROCESS ASPECTS
}

ODWOŁANIE OD UCHWAŁY W SPRAWIE WYKLUCZENIA Z GRONA CZŁONKÓW KOŁA ŁOWIECKIEGO. WYBRANE ASPEKTY PROCESOWE

\begin{abstract}
The aim of the article is to present analyze, as provided for in the provisions of the Hunting Law Act, appeals against the decision of the hunting asssciation regarding the exclusion from among its members as an institution of procedural law, different from classical appeals. The article attempts to determine the essence of membership in a hunting assocition in legal terms. The issues of the jurisdiction of the court authorized to hear the appeal were presented, taking into account the legislative changes made in this respect. Moreover, the analysis of the conditions for the admissibility of substantive examination of the appeal by a common court was carried out.

The last part of the article attempts to define the nature of the appeal as a procedural document and to define its formal requirements.
\end{abstract}

\section{STRESZCZENIE}

Celem artykułu jest analiza przewidzianego w przepisach ustawy - Prawo łowieckie, odwołania od uchwały $\mathrm{w}$ sprawie wykluczenia $\mathrm{z}$ grona członków koła łowieckiego jako instytucji prawa procesowego, odmiennej od klasycznych środków zaskarżenia. 
W artykule podjęto próbę określenia istoty członkostwa w kole łowieckim w ujęciu prawnym. Przedstawiono problematykę właściwości sądu uprawnionego do rozpoznania odwołania, $\mathrm{z}$ uwzględnieniem dokonanych $\mathrm{w}$ tym zakresie zmian legislacyjnych. Ponadto przeprowadzono analizę przesłanek dopuszczalności merytorycznego rozpoznania odwołania przez sąd powszechny. Jednocześnie nakreślono skutki procesowe niewyczerpania odwoławczego trybu wewnątrzorganizacyjnego, a także skutki niezachowania terminu do wniesienia omawianego odwołania do sądu.

W ostatniej części artykułu podjęto natomiast próbę zdefiniowania charakteru odwołania jako pisma procesowego oraz określenia jego wymogów formalnych.

KEYWORDs: membership in hunting association, civil matters, appeals, pleading, jurisdiction

SŁOWA KLUCzOWE: członkostwo w kole łowieckim, sprawa cywilna, środek zaskarżenia, pismo procesowe, właściwość sądu

\section{UWAGI WPROWADZAJĄCE}

Koło łowieckie jest zrzeszeniem osób fizycznych, które mają uprawnienia do polowania i są jednocześnie członkami Zrzeszenia Polski Związek Łowiecki. Organizacja ta skupia określoną grupę osób fizycznych w celu podejmowania określonej aktywności przewidzianej statutem. Pomiędzy kołem łowieckim a jego poszczególnymi członkami występuje więc więź prawna o cechach stosunku cywilnoprawnego (stosunek zrzeszeniowy, korporacyjny).

Członkostwo w kole łowieckim jest dobrowolne, a dobór członków jest autonomiczną decyzją każdego koła. Warunkiem koniecznym do uzyskania statusu członka koła łowieckiego jest oświadczenie zarówno zainteresowanego członkostwem w kole, jak i właściwego organu koła. W konsekwencji sposób nawiązania członkostwa w kole łowieckim pozwala uznać je za zdarzenia cywilnoprawne, prowadzące $\mathrm{w}$ rezultacie do powstania prawa podmiotowego, z którego mogą wynikać poszczególne, jednostkowe uprawnienia członka (postanowienie Sądu Najwyższego z 20 czerwca 2007 r., II CSK 100/07).

Postanowienia Statutu Polskiego Związku Łowieckiego przyznają członkom koła łowieckiego wiele uprawnień zarówno o charakterze majątkowym, jak i niemajątkowym, do których należą m.in.: wybieranie i bycie wybieranym do organów koła, ocenianie działalności koła, składanie wyjaśnienia we wszystkich przypadkach, w których organy koła mają podjąć uchwały doty- 
czące jego osoby i odwoływanie się od tych uchwał na zasadach ustalonych statutem, polowanie indywidualnie i zbiorowo na zasadach określonych Prawem łowieckim oraz uchwałami walnych zgromadzeń, korzystanie z majątku koła na zasadach określonych uchwałą walnego zgromadzenia ( $\$ 40$ Statutu Polskiego Związku Łowieckiego).

Natomiast do obowiązków członków koła łowieckiego należy m.in.: przestrzeganie prawa łowieckiego, Statutu oraz uchwał organów Zrzeszenia i koła, a także dobrych obyczajów, zasad etyki i tradycji łowieckiej oraz zasad selekcji populacyjnej i osobniczej zwierząt łownych, ochrona mienia koła i Zrzeszenia, terminowe uiszczanie składek członkowskich i innych opłat uchwalonych przez walne zgromadzenie, branie czynnego udziału w zwalczaniu kłusownictwa i szkodnictwa łowieckiego, podnoszenie wiedzy łowieckiej oraz doskonalenie umiejętności strzeleckich ( $\$ 41$ Statutu PZE). Utrata członkostwa w kole łowieckim może nastąpić jedynie w określonych sytuacjach, tj. albo w wyniku skreślenia z listy członków ( $\$ 43$ Statutu PZE), albo na skutek wykluczenia członka z koła ( $\$ 44$ Statutu PZŁ). Wykluczenie członka z koła może nastąpić na skutek nieprzestrzegania prawa łowieckiego, statutu bądź uporczywego uchylania się od wykonywania obowiązków nałożonych przez uprawnione organy koła, gdy członek koła rażąco narusza zasady współżycia koleżeńskiego, dobre obyczaje bądź zasady etyki i tradycji łowieckiej.

W celu właściwego funkcjonowania jednostki w tego rodzaju ugrupowaniu ważne jest zapewnienie możności obrony praw tworzących ją członków przed niezgodnym z prawem działaniem samej organizacji. W przypadku członków Polskiego Związku Łowieckiego prawodawca uznał, że potrzebne jest szczególne rozwiązanie ustawowe, które zagwarantuje ochronę prawną członkom zrzeszenia, choć ograniczył ją do spraw nabycia lub utraty członkostwa w nim oraz w kole łowieckim (N.K. Gesek, 2013, s. 161). W przypadku żądania ustalenia członkostwa w kole łowieckim możliwe jest wniesienie przez zainteresowanego powództwa przewidzianego w art. 189 k.p.c. Natomiast środkiem mającym zapewnić kontrolę decyzji w sprawie utraty członkostwa w kole łowieckim - wydanych w trybie wewnątrzorganizacyjnym przez niezależny, bezstronny i niezawisły sąd, jest odwołanie przewidziane w art. 33 ust. 6 Prawa łowieckiego. 


\section{WŁAŚCIWOŚĆ RZECZOWA SĄDU I TRYB ROZPOZNANIA ODWOŁANIA OD UCHWAEY W SPRAWIE WYKLUCZENIA Z GRONA CZŁONKÓW KOŁA ŁOWIECKIEGO}

Postępowanie sądowe wszczęte na skutek odwołania od uchwały w przedmiocie utraty członkostwa w kole łowieckim jest sprawą o cechach sprawy cywilnej i podlega rozpoznaniu przez sąd powszechny na podstawie o przepisów Kodeksu postępowania cywilnego (na temat pojęcia sprawy cywilnej zob. szerzej np.: M. Manowska, 2011, LEX). Nie można jednak pominąć, że kwestia właściwości rzeczowej sądu uprawnionego do rozpoznania odwołania od uchwały w sprawie wykluczenia z grona członków koła łowieckiego nie była jednoznacznie określona przez okres niemal dwudziestu lat obowiązywania Prawa łowieckiego.

Początkowo, tj. aż do 2004 roku, ustawa w ogóle nie zawierała regulacji umożliwiających w sprawach utraty członkostwa w kole łowieckim dochodzenia zainteresowanym praw na drodze sądowej. Uprawnienie to zostało wprowadzone do ustawy w wyniku nowelizacji dokonanej ustawą z 17 czerwca 2004 r. o zmianie ustawy - Prawo łowieckie. Wprawdzie dodany wówczas do treści art. 33 ustawy ustęp 6 przyznawał zainteresowanym w sprawach nabycia lub utraty członkostwa w Polskim Związku Łowieckim oraz utraty członkostwa w kole łowieckim - po wyczerpaniu postępowania wewnątrzorganizacyjnego - możliwość dochodzenia swoich praw na drodze sądowej, niemniej jednak w żaden sposób nie precyzował, w jakim trybie dochodzenie tychże praw powinno następować. Nie określał również właściwości rzeczowej sądu, przed którym dochodzenie tychże praw na drodze sądowej byłoby możliwe. W konsekwencji przepis ten zaczęto odczytywać jako urzeczywistnienie prawa do sądu, o którym mowa w art. 45 Konstytucji (postanowienie Sądu Najwyższego z 20 czerwca 2007 r., III CSK 100/07). W praktyce roszczenie członka koła łowieckiego o ochronę jego członkostwa przed niezgodnym z prawem lub statutem wykluczeniem z koła łowieckiego kierowano do sądu powszechnego jako powództwo, o którym mowa w art. 189 k.p.c. Postępowanie sądowe zatem, co do zasady, toczyło się przed sądem rejonowym.

Istotną zmianę normatywną odnoszącą się do właściwości rzeczowej sądu uprawnionego do rozpoznania odwołania od uchwały w sprawie wykluczenia z grona członków koła łowieckiego wprowadziła ustawa z 12 grudnia 2013 r. o zmianie ustawy - Prawo łowieckie. W wyniku przyjętych zmian właściwość 
rzeczową sądu, do którego należy rozpoznanie odwołania od uchwały koła łowieckiego w sprawie wykluczenia $\mathrm{z}$ listy jego członków, przyznano sądowi okręgowemu. Od wejścia w życie wskazanej ustawy, tj. od 21 kwietnia 2014 r., właściwość rzeczowa sądu, do którego kompetencji należy rozpoznawanie odwołania od uchwały w przedmiocie wykluczenia z kręgu członków koła łowieckiego, jasno wynika z treści przepisu art. 33 ust. 6 Prawa łowieckiego.

Podkreślenia wymaga, że samo określenie właściwości rzeczowej sądu uprawnionego do rozpoznania odwołania od uchwały w sprawie wykluczenia $\mathrm{z}$ listy członków koła łowieckiego nie usunęło jednak wątpliwości co do tego, w jakim trybie odwołanie to powinno zostać rozstrzygnięte. W konsekwencji problematyka ta stała się przedmiotem rozważań Sądu Najwyższego, który ostatecznie uznał, że odwołanie w sprawie utraty członkostwa w kole łowieckim (więc także w sprawie wykluczenia z listy członków koła łowieckiego) oraz nabycia lub utraty członkostwa w Polskim Związku Łowieckim, przewidziane w art. 33 ust. 6 Prawa łowieckiego, sąd okręgowy rozpoznaje jako sąd drugiej instancji, stosując odpowiednio przepisy o apelacji (uchwała Sądu Najwyższego z 28 września 2016 r., III CZP 45/16; uchwała Sądu Najwyższego z 28 września 2016 r., III CZP 46/16, postanowienie Sądu Najwyższego z 9 lutego 2017 r., IV CZ 102/16).

\section{Przesłanki dopuszczalności rozpoznania PRZEZ SĄD ODWOEANIA OD UCHWAEY W SPRAWIE WYKLUCZENIA Z GRONA CZŁONKÓW KOŁA ŁoWIECKIEgo W ŚWIetle ART. 33 UST. 6 PraWA LOWIECKIEGO}

Możliwość badania przez sąd merytorycznej zasadności uchwały w sprawie wykluczenia z kręgu członków koła łowieckiego jest dopuszczalna wyłącznie w trybie postępowania wszczętego na podstawie art. 33 ust. 6 ustawy - Prawo łowieckie. Wskazany przepis określa przesłanki, które warunkują możliwość zakwestionowania tego rodzaju uchwały na drodze sądowej. Są nimi: wyczerpanie odwoławczego postępowania wewnątrzorganizacyjnego oraz zachowanie terminu do wniesienia odwołania. Dla skutecznego wniesienia odwołania w tym zakresie koniecze jest, aby wymienione przesłanki wystąpiły łącznie. 
Tryb postępowania wewnątrzorganizacyjnego określają przepisy Działu IV Rozdziału XVIII Statutu Polskiego Związku Łowieckiego. Decyzje o wykreśleniu członka $\mathrm{z}$ listy koła łowieckiego są podejmowane w głosowaniu tajnym, większością 2/3 głosów, w formie uchwały ( $\$ 168$ ust. 4 i $\$ 169$ ust. 2 Statutu PZŁ). Postanowienia Statutu przewidują również, że uchwały w sprawie wykluczenia z koła wymagają uzasadnienia. Zainteresowany natomiast tego rodzaju uchwałę powinien otrzymać na piśmie z uzasadnieniem. Powinien także zostać pouczony o trybie odwołania ( $\$ 170$ ust. 3 Statutu PZŁ).

Z paragrafu 171 ust. 2 Statutu wynika zaś, że odwołanie przysługuje od uchwał zarządu koła do walnego zgromadzenia koła, walnego zgromadzenia koła do zarządu okręgowego, zarządu okręgowego do okręgowej rady łowieckiej, Zarządu Głównego i okręgowej rady łowieckiej do Naczelnej Rady Łowieckiej. Zauważyć należy, że wprawdzie z przywołanego powyżej $\$ 171$ ust. 2 Statutu nie wynika wprost, że wskazany tryb zaskarżania uchwał odnosi się jedynie do uchwał organów podjętych w „pierwszej instancji”, jednak do wniosku takiego prowadzi ust. 1 wskazanej regulacji. Uchwały podjęte w trybie odwoławczym są prawomocne, a zatem wyczerpanie trybu z $\$ 171$ ust. 2 Statutu jest równoznaczne $\mathrm{z}$ wyczerpaniem trybu wewnątrzorganizacyjnego. W przypadku pominięcia przez zainteresowanego drogi postępowania wewnątrzorganizacyjnego i złożenia odwołania przewidzianego przez art. 33 ust. 6 ustawy bezpośrednio do sądu okręgowego taki środek powinien zostać odrzucony przez sąd na podstawie odpowiednio stosowanego art. $199 \$ 1$ pkt 1 k.p.c. (M. Słomski, 2015, LEX).

Drugą z przesłanek skutecznego zainicjowania postępowania w przedmiocie odwołania do sądu okręgowego jest zachowanie terminu do jego wniesienia. Ustawodawca bowiem na wniesienie odwołania przewidział termin 14 dni od otrzymania rozstrzygnięcia kończącego postępowanie. Bezsprzeczne jest, że ustalenie tego, czy odwołanie zostało wniesione z zachowaniem ustawowego terminu, następuje zgodnie z przepisami Kodeksu postępowania cywilnego.

Natomiast dla oceny, jakie skutki procesowe będzie wywoływać ewentualne uchybienie terminu, o którym mowa w art. 33 ust. 6 ustawy - Prawo łowieckie, kluczowe staje się określenie charakteru terminu do wystąpienia 
z odwołaniem. Od ustalenia, czy termin ten jest terminem prawa materialnego, czy też prawa procesowego, uzależnione jest bowiem to, czy skarżący może skutecznie domagać się przywrócenia terminu, czy też uchybienie terminu określonego w art. 33 ust. 6 ustawy Prawo łowieckie implikuje bezwzględną konieczność oddalenia odwołania bez potrzeby dokonywania jego oceny.

Przypomnieć zatem należy, że o charakterze materialnoprawnym czy procesowym konkretnego przepisu nie decyduje, w jakim akcie prawnym czy też w jakim miejscu został zamieszczony, lecz jego treść i wynikająca z niej funkcja, którą przepis ten ma spełnić i jego istota (uzasadnienie uchwały Sądu Najwyższego z 14 marca 1986 r., III PZP 8/86). O zakwalifikowaniu normy prawnej ustanawiającej termin przesądzać może tylko przedmiot regulacji. Ustalić zatem należy, czy dotyczy kształtowania praw lub obowiązków, czy terminu dokonania czynności procesowej w toku postępowania cywilnego.

Termin przewidziany w art. 33 ust. 6 ustawy - Prawo łowieckie służy do ostatecznego ukształtowania praw i obowiązków jednostki w ramach cywilnoprawnego stosunku materialnego, jakim jest członkostwo w kole łowieckim. Stwierdzić zatem należy, że termin do wniesienia odwołania od uchwały w przedmiocie wykluczenia $\mathrm{z}$ listy członków koła łowieckiego jest terminem prawa materialnego, klasyfikowanym $\mathrm{w}$ teorii prawa jako termin prekluzji sądowej (zob. szerzej: J. Gwiazdomorski, 1968, s. 87-109). Nie ulega wątpliwości, że termin ten definiuje i zarazem stabilizuje sytuację prawną podmiotów, których pozycja zostaje określona przede wszystkim wprost na podstawie przepisów prawa i związanych z tym zdarzeń, dla których czas odgrywa zasadniczą rolę.

W konsekwencji niezachowanie terminu dla realizacji określonego w przepisie prawa powoduje, że prawo to wygasa i nie może być dochodzone przed sądem czy innym organem. Tym samym termin ten nie może być przywrócony na podstawie art. 168 k.p.c. Należy przy tym zwrócić uwagę, że przepisy prawa materialnego określające termin do skorzystania z określonego uprawnienia nie dopuszczają możliwości nieuwzględnienia przez sąd upływu terminu, nawet jeżeli opóźnienie w wytoczeniu powództwa jest usprawiedliwione wyjątkowymi okolicznościami (wyrok Sądu Apelacyjnego w Poznaniu z 3 listopada 1994 r., I ACa 326/94). Nie jest także 
możliwe uwzględnienie odwołania wniesionego z uchybieniem terminowi zawitemu, przy zastosowaniu art. 5 k.c., który posiada charakter klauzuli generalnej. Pominięcie skutków upływu terminów materialnoprawnych na podstawie wskazanego przepisu prowadziłoby bowiem do zaburzenia porządku prawnego poprzez „przywrócenie” uprawnienia, które wolą ustawodawcy wygasło.

Uchybienie terminowi do złożenia odwołania w sprawie wykluczenia z grona członków koła łowieckiego powoduje, że termin ten wyekspiruje, a odwołanie wniesione po terminie musi zostać oddalone.

\section{ODWOEANIE OD UCHWAEY W SPRAWIE WYKLUCZENIA Z GRONA CZŁONKÓW KOŁA ŁOWIECKIEGO JAKO PISMO PROCESOWE}

Fakt, że odwołanie podlega rozpoznaniu przez sąd okręgowy stosujący odpowiednio przepisy o apelacji, z całą pewnością nie pozwala na uznanie, że jest ono odpowiednikiem pozwu (R. Kulski, 2018, s. 32). Nie jest to także klasyczny środek odwoławczy przewidziany w Kodeksie postępowania cywilnego. Stwierdzić zatem należy, że ustanowione w przepisie art. 33 ust. 6 Prawa łowieckiego odwołanie jest swoistym środkiem zaskarżenia. Ten szczególny charakter determinuje również wymogi formalne odwołania jako pisma procesowego wszczynającego postępowanie sądowego w sprawie uchwały o wykluczeniu z grona członków koła łowieckiego. Z jednej bowiem strony konieczne jest, aby odwołanie spełniało wymogi formalne przewidziane przepisami Kodeksu postępowania cywilnego dla pierwszego pisma procesowego $\mathrm{w}$ sprawie, $\mathrm{z}$ drugiej natomiast konieczne jest, aby odwołanie zawierało elementy charakterystyczne dla środków zaskarżenia. Zachowanie przez stronę właściwej formy przewidzianej dla danego środka odwoławczego jest natomiast jedną z przesłanek jego dopuszczalności (B. Bladowski, 2013, LEX).

Żaden z przepisów Prawa łowieckiego nie określa wymogów formalnych odwołania od uchwały w sprawie wykluczenia z listy członków koła łowieckiego. Prowadzi to więc do wniosku, że odwołanie jako quasi-środek odwoławczy musi spełniać wymogi przewidziane dla pism procesowych przez Kodeks postępowania cywilnego. Stwierdzić przy tym należy, że sko- 
ro odwołanie w sprawach dotyczących wykluczenia z listy członków koła łowieckiego de facto jest pierwszym pismem w sprawie, odpowiednie zastosowanie przepisów art. 368 k.p.c., w celu sprecyzowania wszystkich niezbędnych elementów odwołania jako kwalifikowanego pisma procesowego, jest niewystarczające.

Prawidłowo zatem sformułowane odwołanie powinno spełniać także wymogi formalne dla pisma procesowego, które jest pierwszym pismem w sprawie, przewidziane $\mathrm{w}$ przepisie art. $126 \$ 2$ k.p.c. Konieczne jest więc oznaczenie miejsca zamieszkania lub siedziby i adresy stron, oznaczenie miejsca zamieszkania lub siedziby i adresy przedstawicieli ustawowych i pełnomocników stron, numer Powszechnego Elektronicznego Systemu Ewidencji Ludności (PESEL) lub numer identyfikacji podatkowej (NIP) powoda będącego osobą fizyczną, jeżeli jest on obowiązany do jego posiadania lub posiada go, nie mając takiego obowiązku.

Mając natomiast na uwadze, że apelacja nie jest pierwszym pismem procesowym w sprawie, przyjmuje się, że nie musi zawierać oznaczenia miejsca zamieszkania bądź siedziby stron, chyba że z wniesieniem apelacji połączone jest przystąpienie określonego podmiotu do sprawy (M. Manowska, 2011, LEX). Tożsame uwagi należy poczynić w zakresie konieczności wskazania numeru indentyfikacyjnego skarżącego oraz informacji dotyczących osób działających za skarżącego.

Ponadto, stosownie do treści art. $126 \$ 1$ k.p.c., odwołanie powinno zawierać oznaczenie sądu, do którego jest skierowane, imię i nazwisko lub nazwę stron, ich przedstawicieli ustawowych i pełnomocników, oznaczenie rodzaju pisma, podpis strony albo jej przedstawiciela ustawowego lub pełnomocnika.

W przypadku reprezentowania skarżącego przez pełnomocnika konieczne jest dołączenie do odwołania dokumentu pełnomocnictwa, zgodnie bowiem $z$ art. $89 \$ 1$ k.p.c. pełnomocnik jest obowiązany przy pierwszej czynności procesowej dołączyć do akt sprawy pełnomocnictwo z podpisem mocodawcy lub wierzytelny odpis pełnomocnictwa wraz z odpisem dla strony przeciwnej.

Przyjęcie natomiast, że odwołanie jest swoistym środkiem zaskarżenia, determinuje, że w swojej treści powinno zawierać oznaczenie uchwał, które stanowią podstawę do jego wniesienia ze wskazaniem zakresu ich zaskarże- 
nia, zwięzłe przedstawienie zarzutów, powołanie, w razie potrzeby, nowych faktów i dowodów oraz wykazanie, że ich powołanie w postępowaniu wewnątrzorganizacyjnym nie było możliwe albo że potrzeba powołania się na nie wynikła później, oraz wniosek o zmianę lub o uchylenie zaskarżonej uchwały z zaznaczeniem zakresu żądanej zmiany lub uchylenia.

Za nieprawdopodobną należy uznać możliwość sformułowania zakresu zaskarżenia, tak aby kwestionować rozstrzygnięcie o wykluczeniu z członków koła łowieckiego jedynie w części. Żaden z przepisów Prawa łowieckiego ani żadne z postanowień Statutu nie przewiduje bowiem możliwości częściowego wykluczenia z kręgu członków koła łowieckiego.

Odnosząc się natomiast do obowiązku zwięzłego przedstawienia zarzutów, należy podkreślić, że w odwołaniu, tak jak w apelacji, możliwe jest podnoszenie zarzutów dotyczących ustalenia stanu faktycznego, naruszenia przepisów procesowych oraz naruszenia prawa materialnego. Niemniej jednak należy pamiętać, że poprawnie skonstruowany zarzut naruszenia prawa materialnego nie może odnosić się jedynie do postanowień Statutu Polskiego Związku Łowieckiego, a konieczne staje się ewentualne zarzucenie art. 65 Kodeksu cywilnego poprzez błędną wykładnię jego postanowień.

Nie można także pominąć, że jednym z warunków skierowania odwołania od uchwały w sprawie wykluczenia z grona członków koła łowieckiego do merytorycznego rozpoznania jest jego opłacenie. Zgodnie bowiem $\mathrm{z}$ art. $126^{2}$ $\$ 1$ k.p.c. sąd nie podejmie żadnej czynności na skutek pisma, od którego nie została uiszczona należna opłata.

Kwestii wysokości opłaty sądowej od odwołania nie regulują przepisy Prawa łowieckiego. Wysokość tej opłaty nie została także przewidziana wprost w ustawie z 28 lipca 2005 r. o kosztach sądowych w sprawach cywilnych. Mając jednak na względzie, że członkostwo w kole łowieckim jest konstrukcją zbliżoną do członkostwa w spółdzielni, zasadne w kwestii ustalenia wymiaru opłaty sądowej od odwołania jest zastosowanie stawki 200 zł przewidzianej dla powództwa o uchylenie uchwały organu spółdzielni (art. 27 pkt 8 ustawy o kosztach sądowych w sprawach cywilnych).

Końcowo należy wskazać, że ewentualne braki odwołania podlegają usunięciu na zarządzenie przewodniczącego, a ich nieusunięcie lub nieprawidłowe usunięcie będzie skutkować odrzuceniem odwołania. 


\section{WNIOSKI}

Przepis art. 33 ust. 6 Prawa łowieckiego wprowadza szczególny środek zaskarżenia skierowany przeciwko uchwałom $\mathrm{w}$ sprawie wykluczenia $\mathrm{z}$ grona członków koła łowieckiego, jakim jest odwołanie. Instrument ten umożliwia zainteresowanym podmiotom weryfikację zasadności uchwały organu korporacyjnego przez niezależny, bezstronny i niezawisły sąd. Zwrócić jednak należy uwagę, że analizowany środek odwoławczy wykazuje pewne odrębności od klasycznych środków zaskarżenia przewidzianych w Kodeksie postępowania cywilnego, tj. zażalenia i apelacji. W szczególności nie może ujść uwadze charakter terminu do jego wniesienia. W przeciwieństwie bowiem do terminu złożenia zażalenia czy apelacji nie jest on terminem procesowym, a jego niezachowanie będzie skutkować oddaleniem odwołania. Mając zaś na uwadze, że odwołanie w sprawach dotyczących wykluczenia z listy członków koła łowieckiego de facto jest pierwszym pismem w sprawie, stwierdzić także należy, że odpowiednie zastosowanie przepisów art. 368 k.p.c., w celu sprecyzowania wszystkich niezbędnych elementów odwołania jako kwalifikowanego pisma procesowego, jest niewystarczające.

\section{References}

\section{Źródła prawa}

Ustawa z 17 listopada 1964 r. - Kodeks postępowania cywilnego (Dz.U. z 1964 r. nr 43, poz. 296 z poźn. zm.).

Ustawa z 13 października 1995 r. - Prawo łowieckie (t.j. Dz.U. z 2018 r. poz. 2033 z późn. zm.).

Ustawa z 17 czerwca 2004 r. o zmianie ustawy - Prawo łowieckie (Dz.U. z 2004 r. nr 172, poz. 1802).

Ustawa z 28 lipca 2005 r. o kosztach sądowych w sprawach cywilnych (t.j. Dz.U. z 2018 r. poz. 300 z późn. zm.).

Ustawa z 12 grudnia 2013 r. o zmianie ustawy - Prawo łowieckie (Dz.U. z 2014 r. poz. 228).

Załącznik do uchwały XXI Krajowego Zjazdu Delegatów Polskiego Związku Łowieckiego z 2 lipca 2005 r. - Statut Polskiego Związku Łowieckiego 


\section{Literatura}

Bladowski, B. (2013). Środki odwoławcze w postępowaniu cywilnym, Warszawa: Wydawnictwo Wolters Kluwer, wersja dostępna w serwisie LEX. ISBN 9788326442193.

Gesek, N.K (2013). Glosa do wyroku TK $z$ dnia 6 listopada 2012 r. (sygn. akt K 21/11), Przegląd Sejmowy 5(118)/2013. ISSN 1230-5502.

Gwiazdomorski, J. (1968). Terminy zawite do dochodzenia roszczeń $w$ kodeksie cywilnym, Ruch Prawniczy, Ekonomiczny i Socjologiczny 3/1968. ISSN 0035-9629.

Kulski, R. (2018). Glosa do uchwały Sądu Najwyższego z dnia 28 września 2016 roku, III CZP 45/16, Orzecznictwo Sądów Polskich 100/10/2018. ISSN 0867-1850.

Manowska, M. (2011). Komentarz do art. 1, [w:] Manowska M. (red.), Kodeks postępowania cywilnego. Komentarz, tom. 1 (art. $\left.1-505^{37}\right)$, Warszawa: LexisNexis, wersja dostępna w serwisie LEX.

Manowska, M. (2011). Komentarz do art. 368, [w:] Manowska M. (red.), Kodeks postępowania cywilnego. Komentarz, tom 1 (art. 1-505 ${ }^{37}$ ), Warszawa: LexisNexis, wersja dostępna w serwisie LEX. ISBN 9788376208466.

Słomski M. (2015). Komentarz do art. 33, [w:[ Pązik A. (red.), Słomski M. (red.), Prawo łowieckie. Komentarz, Warszawa: Wydawnictwo Wolters Kluwer, wersja dostępna w serwisie LEX. ISBN 9788326481475.

\section{Orzeczenia}

Uchwała Sądu Najwyższego z 14 marca 1986 r., III PZP 8/86, OSNC 12/86/194.

Uchwała Sądu Najwyższego z 28 września 2016 r., III CZP 45/16, Lex 2113362.

Uchwała Sądu Najwyższego z 28 września 2016 r., III CZP 46/16, Lex 2113361.

Postanowienie Sądu Najwyższego z 20 czerwca 2007 r., II CSK 100/07, Lex 347287.

Postanowienie Sądu Najwyższego z 9 lutego 2017 r., IV CZ 102/16, Lex 2255430.

Wyrok Sądu Apelacyjnego w Poznaniu z 3 listopada 1994 r., I ACa 326/94, Lex 23687. 